Psychology of Language and Communication 2014, Vol. 18, No. 1

DE GRUYTER

OPEN

DOI: $10.2478 /$ plc-2014-0002

IWONA JAKUBOWSKA-BRANICKA

University of Warsaw

\title{
LANGUAGE AS A TOOL CREATING AND DIVIDING COMMUNITIES. DANGEROUS USE OF ASYMMETRIC COUNTERCONCEPTS
}

\begin{abstract}
The paper discusses the role of language in shaping social and political reality. Referring to the theory of the sociology of knowledge, symbolic interactionism and theory related to sociolinguistics, the author makes the assumption that language understood as a tool that assigns meaning and defines reality has a decisive influence on individual awareness and knowledge about reality, and simultaneously also on activities undertaken by individuals. Moreover, in the opinion of many theoreticians who represent the above disciplines of knowledge, the knowledge about reality transferred by means of language creates cognitive schemes in awareness through which an individual perceives and defines reality. In this sense it may be said that manipulation of images of reality through language is also a manipulation of social reality.
\end{abstract}

Key words: language, community, granfalloon, dogmatic narrations, asymmetric counterconcepts

\section{The notions of community and identity}

The notion of community is one of the basic and most important notions in social and humanities studies. Nevertheless, there is no common definition of a community and the scope of such a definition is being discussed all the time. This is due to differences in approaching the problem. Thus, for instance, symbolism - discovered by 19th-century thinkers - identified a community with the idea of good society and all types of relationships that are characterized by personal closeness, emotional profoundness, internal commitment, social coherence and continuity in time. Some people were afraid that these features disappear in the

Address for correspondence: Iwona Jakubowska-Branicka, Institute of Applied Social Sciences, University of Warsaw, Nowy Świat 69, 00-927 Warsaw, Poland. E-mail: iwona.branicka@isns.uw.edu.pl 
process of transition from rural societies to municipal and industrial society. F. Tonnies, who is considered the author of the community theory, in his work Community and Society presented pictures of both these forms of social relation in the form of ideal types, and he contrasted social relationships based on solidarism in type one with vast and impersonal relationships that are characteristic of industrializing societies. Problems with definitions encountered by sociology of community result from three difficulties. Firstly, the notion of community is often used for both identification and approval of a specific form of social relation. Secondly, the characteristics of social relationships that prove the existence of solidaristic relationships typical for a community are not defined clearly and objectively, which is related to the third difficulty of empirical identification of communities (Marshall, 2005).

Regardless of problems with definition, or maybe thanks to the open nature of the term "community", it is sometimes used in relation to different social collectives, such as a nation, an ethnic, rural, religious, cultural, worldview, primitive, open or closed community, to mention only the most popular contexts. There seems to be no theoretical abuse in this, because all definitions of a community have a common denominator. Its essence lies in the assumption that the main feature of a community is a strong psychological bond felt by its members that is much stronger than any non-community ties, as well as community of beliefs, feelings and accepted values.

If we assume this point of view, it is of secondary importance whether such ties have been established on the basis of objectively conditioned relationships, e.g. kinship, neighborhood, territoriality, or whether the community developed as a result of various other circumstances, sometimes accidental and sometimes initiated by someone for this very purpose.

The term "community" has an essential meaning in the context of the discussion centering on both society on a global level and human beings as the main subject of such society.

The notion of identity has been the subject of interest of social sciences and psychology for several decades. In the beginning the problem of identity was applied only to the individual, but soon the notion of collective identity appeared in the language of science. One could say that the notion of collective identity developed due to the emergence of the concept of individual identity from traditional ways of characterizing communities that were probably derived from the prototypical categories of "national character" and "self-stereotype" (Bokszański, 2006).

The notion of collective identity, like many other terms in social sciences and humanities, is sometimes problematic due to its indeterminate definition. Collective identity is understood by some theoreticians as "collective consciousness", supra-individual existence, with the result that some authors strongly oppose the use of this concept (Bokszański, 2006). But collective identity may also be 
understood as self-identification of an individual in reference to the community. Zbigniew Bokszański quotes Richard Jenkins's opinion that is it unreasonable for sociology to separate collective identities from individual ones so strictly, while the forms of "individually single" identity and "shared collective" identity are very strongly related to each other. Why would we challenge the existence of collective identity if it is generally assumed that community is multiplicity of individuals who perceive one another as similar enough to call themselves "we"? Why are perceptions, beliefs and recognized substantive similarity not to be considered as the identity of a community that also has the function of integrating individuals into a group (Bokszański, 2006)? Such self-identifications of individuals are most often applied to national, ethnic, religious or cultural identity related to membership of a certain social group.

Like many authors who have problems with defining the notions of community and identity, we encounter an important theoretical problem in our reasoning. Not every group or community fulfills the main criterion in the definition of community. It seems, however, that for the individual's mechanism of self-identification with a group and the mechanism of determining one's identity through reference to a group to work, an individual must perceive the group as a community to which he or she belongs, a community with which he or she has strong ties as well as sharing its opinions and accepted values. This assumption is essential for our further discussion.

As mentioned earlier, a community bond can be established on the basis of objectively existing relationships, such as kinship, ethnicity, national or cultural affiliation, but it can also be the result of activities that have been specially undertaken for such a purpose.

\section{The granfalloon problem in the field of social psychology}

One of the best-known mechanisms of creating a group - one that has the features of a community, as we will later see - is the granfalloon technique. This method is both very effective and dangerous for the development of social life, and that danger is related to its efficiency. The term and notion of granfalloon was introduced to the language of literature by Kurt Vonnegut in his famous novel Cat's Cradle published in 1963. The notion was considered to be so evocative and theoretically promising that it was developed and included in scientific theory. To be as brief as possible, granfalloon is defined as a group in which members share the same feeling of identity and purpose, but for whom their mutual relationships are meaningless and pointless, at least from an "objective" point of view. Granfalloon tactics is the tactics of referring to group pride.

In the field of social psychology, the granfalloon problem was considered by Henri Tajfel. He applied what is known as the minimal group paradigm that serves as the basis for a persuasive technique that turned out to have a strong 
impact on emotions. By means of this procedure, groups of people are established using the most trivial and meaningless criteria, for instance a coin toss, eye color or date of birth. In Vonnegut's language this means creating proud and senseless associations of human beings.

The results of Tajfel's research are very interesting. Despite the fact that the subjects in his study were absolute strangers before the experiment, did not contact one another during the study and had probably never met in the past, while their actions were completely anonymous, they acted as if they were good friends or close relatives with those linked to them by means of a meaningless common label. The subjects stated that they liked people who had the same label as they did. They assessed them as probably having nicer personalities and obtaining better results than members of the out-group who had received a different label. According to the experiment's authors, the most striking fact is that the subjects granted more money and prizes to those who had the same label than to members of the out-group.

Trying to find out why granfalloon works this way, the researchers discovered two main psychological processes: one cognitive and the other motivational. First of all, awareness of being a member of a group is used to divide the world and helps with its understanding. In the reassuring awareness that one is a member of a group, one exaggerates differences between groups and also emphasizes similarities among granfalloon members. Consequently, members of the outgroup are dehumanized, since they are represented in one's mind by insulting and discrediting labels. Furthermore, the feeling of belonging to a group is a source of pride and self-esteem (Pratkanis \& Aronson, 2003).

The granfalloon technique is very frequently used by politicians and by those who have power in areas that have nothing in common in politics sensu stricto, for instance in office politics. Nothing can offer you greater success than the winning granfalloon. Creating an opposition between US and THEM and launching an ethnocentric mechanism at the same time helps us initiate, fight and often win wars on all fronts. Since it leads to favoring of "us", social categorization, i.e. grouping phenomena into categories and giving them names that would arrange incoming information and facilitate one's orientation in the world, also leads to conflict. Another source of conflicts originating from the categorization process is the drive to achieve a positively valued difference between one's own group and other groups, i.e. showing that "We are better than they are" and "They are worse than we are" (Skarżyńska, 2011, p. 250).

Anthony Pratkanis and Elliot Aronson (Pratkanis \& Aronson, 2003, p. 56) describe two types of granfalloon: inclusive and exclusive granfalloon. Creating an exclusive granfalloon is based on the aforementioned tactics of announcing the superiority of "us" by discrediting and ridiculing "others". The essence of establishing an exclusive granfalloon is to search for and emphasize differences between the separate groups. 
When discussing the essence of inclusive granfalloon, the authors give the example of Abraham Lincoln's Gettysburg Address in 1863 at the cemetery of one of the bloodiest battles of the American Civil War, delivered at a commemoration with families and friends of soldiers who died on both sides. In this address Lincoln is deemed to have defined what it means to "be American", uniting the North with the South and thus establishing the American People. Pratkanis and Aronson define this granfalloon as being inclusive, since Lincoln was able to find similarities, a common denominator that united people who had been on opposite sides. It seems, however, that even inclusive granfalloons that are open to a search for similarities with those who were outsiders before, are always exclusive in relation to people with whom no similarity can be found. Nevertheless, they provide a basis for peace, understanding and cooperation, and they prevent conflicts and wars.

\section{Language as a tool of creating granfalloons}

Language is a tool of creating granfalloons (Jakubowska-Branicka, 2013). Transfer and exchange of information is the essence of communication among individuals. Regardless of that, different sources of information transfer may be intended to send messages containing different contents, such messages may also be differently received and interpreted by their recipients.

If we assume the perspective of symbolic interactionism, communication is an extremely complex process. According to this theory, every social interaction is understood as communication by means of symbols. Only the occurrence of symbolic interaction signifies the establishment of social relationships in the full meaning of the word.

According to Herbert Blumer (2007), symbolic interactionism is based on three simple premises. First of all, human beings act in relation to objects on the basis of the meaning such objects have for them. Such objects include everything that may be perceived by an individual in his or her world, including both physical objects, such as trees or houses; other human beings, like their mother or a teacher; categories of people, like friends or enemies; institutions, like school or government; ideals, like independence or honesty; other people's actions, like orders or requests or, finally, all situations encountered by an individual in his or her everyday life. According to the second premise, the meaning of such objects originates from social interactions that link an individual with his or her surroundings. Thirdly, people use meanings and modify them in interpretation processes performed in relation to encountered objects.

According to the position of symbolic interactionism, meanings that objects have for people are of central importance. Symbolic interactionism rejects the opinion that meaning emanates from the internal properties of an object or is created as a combination of psychological elements in the psyche of a given in- 
dividual. It is deemed to be a result of interactions between people, and since an individual interacts constantly throughout his or her life, such meanings may be modified as a result of the impact exercised by the surroundings and the related interpretation process that consists of two separate stages. First, the individual points to an item that is meaningful to him or her, and then in the process of communication, interpretation becomes a matter of dealing with meanings.

Thus, according to symbolic interactionism, the "worlds" existing for human beings and groups of people consist of "objects", and objects are products of symbolic interaction. Everything that can be indicated is an object and for the sake of convenience Blumer proposes a division of objects into three categories: physical objects, social objects and abstract objects, such as ideas or moral principles. The nature of an object consists of the meaning the object has for a given person. Meaning includes the way in which the object is perceived by that person and the way in which the person is prepared to act in relation to the object, and how the person is prepared to talk about it. An object may have various meanings for different individuals: the same tree is a different item for a botanist and for a poet; one ethnic group may perceive members of another group as a completely different kind of object. In its essence, an object's meaning results from the way in which it has been defined by others with whom given individuals interact, since thanks to the indications of other people we find out what a given object is (e.g. that mother is mother, etc.). The process of mutual indications gives rise to common objects, i.e. objects that have the same meaning for a given group of people and are perceived by that group in the same way.

Adopting such premises entails a few significant consequences. First of all, according to Blumer, a different image of the environment or rather milieu of human beings is created. From their point of view it consists only of items recognized by and known to them. The nature of such an environment results from the meaning of objects constituting this environment for those people. Both individuals and groups living in the same space may live in very different environments, "they may live next to each other, but in different worlds", and the term "world" is considered by Blumer to be more appropriate than "environment" since it is a world of objects with which they deal and in respect to which they undertake their activities. Secondly, as mentioned earlier, objects, i.e. their meanings, should be perceived as social creations formed in the process of their defining and interpretation. The meaning of every object must be shaped, learnt and communicated in the process of indicating, which is a social process, and meaning may be modified in the process of social interactions (Blumer, 2007, p. 12).

The problem of multiplicity of parallel worlds was also analyzed by Alfred Schütz, who referred to the theory of American interactionism but considered it in a different scientific paradigm (Schütz, 2008). When explaining the theory of symbolic interactionism, Blumer referred to the works of George H. Mead, while Schütz, being a philosopher - to the works of Edmund Husserl, and he promoted 
the idea that every individual has his or her "lifeworld" which is assumed to be something obvious but is different from the "worlds" of other people. In spite of this, people believe that they share the same "lifeworld" and act as if they lived in a common world.

Commencing his analysis of the reality of the "everyday lifeworld", Schütz starts from the assumption that such a world should be understood as an intersubjective world that had existed long before we were born and had been experienced and interpreted by others, our ancestors, as an organized world. At present that world is available for our experience and interpretation. And any interpretation of the world is only possible on the basis of prior experience, including our own experience and the experience passed to us by our parents and teachers, and is used as a scheme of reference in the form of "knowledge at hand".

Schütz, similarly to Mead and Blumer, is of the opinion that meaning is not embedded in the properties of an object but results from the interpretation made by an individual. He is interested in the subjective meaning that is granted by a human to certain experience of his or her spontaneous life. What is perceived by an observer as being objectively the same act may have completely different meanings for the acting subject or even may have no meaning at all. As he writes "Meaning ... is not a quality inherent to certain experiences emerging within our stream of consciousness but the result of an interpretation of a past experience looked at from the present Now with a reflective attitude" (Schütz, 2008, p. 19), and furthermore: "We speak of provinces of meaning and not of sub-universes because it is the meaning of our experiences and not the ontological structure of the objects which constitutes reality" (Schütz, 2008, p. 34).

Multiple meanings assigned to the same objects by different people lead to the construction of multiple alternative realities.

The above-mentioned notion of "knowledge at hand" is considered by Schütz to be essential in his theory. It provides grounds for interpreting surrounding phenomena. It includes knowledge according to which "the world we live in is a world of well circumscribed objects with definite qualities, objects among which we move, which resist us and upon which we may act. To the natural attitude the world is not and never has been a mere aggregate of colored spots, incoherent noises, centers of warmth and cold. Philosophical or psychological analysis of the constitution of our experiences may afterwards, retrospectively, describe how elements of this world affect our senses, how we passively perceive them in an indistinct and confused way, how by active apperception our mind singles out certain features from the perceptional field, conceiving them as well delineated things which stand out over against a more or less inarticulated background or horizon" (Schütz, 2008, p. 18).

The assumption that knowledge - being a combination of knowledge transferred by others and knowledge obtained from one's own experience - provides a foundation for interpreting the surrounding reality, leads us to the theory of 
the sociology of knowledge. The sociology of knowledge deals with the issue of how our knowledge about reality influences its further perception and decisions made. The development of theory of social creation of reality was strongly supported by the work entitled The Social Construction of Reality by Peter L. Berger and Thomas Luckmann published in $1966^{1}$. In the opinion of the authors, from a sociological point of view two facts decide about the human world. First of all, it is the social nature of humans, and secondly human relations with the world effected through symbols. They both decide to a significant extent on what becomes a human being's social reality. Social reality has the value of reality if meanings are assigned to it. Certain phenomena may be perceived as processes, facts and relations if they receive meanings, certain symbolic content. Knowledge, even the simplest kind, is a result of arranging information, such arranging being the result of human beings' social existence. The simplest human inclinations, such as referring certain activities to habits and then typification of actions, relations or persons, through social interactions result in the construction of facts that are external in relation to an individual, that are the "building material" of that individual's reality. Furthermore, institutionalization processes are responsible for various mechanisms legitimating established institutions all the way to developed symbolic universes, and not only provide the reality thus created with the status of an objective sphere of facts, but cause it to make individuals submit to its laws (Niżnik, 1983).

Berger and Luckmann write: "The world of everyday life is not only taken for granted as reality by the ordinary members of society in the subjectively meaningful conduct of their lives. It is a world that originates in their thoughts and actions, and is maintained as real by these. Before turning to our main task we must, therefore, attempt to clarify the foundations of knowledge in everyday life, to wit, the objectivations of subjective processes (and meanings) by which the intersubjective common-sense world is constructed" (Berger \& Luckmann, 1983, p. 50).

\section{Language as a tool that gives meaning}

Meaning, i.e. creation of signs by people, is an objectivation of decisive importance. It is different from other objectivations due to its explicitly visible intent to play the role of an indicator of subjective meanings.

Signs make up many systems. Still, language is the most important system of signs in human society. "Language now constructs immense edifices of symbolic representations that appear to tower over the reality of everyday life like

\footnotetext{
${ }^{1}$ In Polish sociological literature one sometimes encounters the term "social constructivism". The terms "social constructionism" and "social constructivism" are usually used interchangeably, although sometimes authors apply them to notions that are not quite the same. For the purpose of this paper I will use the term "social constructionism".
} 
gigantic presences from another world. Religion, philosophy, art, and science are the historically most important symbol systems of this kind ... Language is capable not only of constructing symbols that are highly abstracted from everyday experience, but also of 'bringing back' these symbols and appresenting them as objectively real elements in everyday life. In this manner, symbolism and symbolic language become essential constituents of the reality of everyday life and of the common-sense apprehension of this reality. I live in a world of signs and symbols every day" (Berger \& Luckmann, 1983, p. 77).

Language builds semantic fields, i.e. spheres of meanings with limited scope in respect to language; language creates classification schemes that differentiate things in respect to their type, it makes it possible to arrange individual social experience. Language creates the social resource of knowledge that provides schemes typifying not only others, but also typifying all kinds of events and experience, both social and natural.

It is due to language that we perceive everyday reality as being ordered and objectivized. It is the language used in everyday life that provides us constantly with necessary objectivations and defines an order thanks to which they are understandable and in which everyday life is meaningful for us. Language establishes the landmarks of our life in society and fills this life with meaningful things. Objectivation of the world is the result of knowledge "that there is an ongoing correspondence between my meanings and their meanings in this world, that we share a common sense about its reality" (Berger \& Luckmann, 1983, p. 55).

Typifying schemes necessary for the capability to define reality, typifications of all kinds of social and natural events and experience are also provided by the social knowledge resource. In this sense, the resource of notions at the disposal of an individual will determine the way in which reality is perceived by that individual, and such notions are connotations of terms included in the language.

Social constructionism invokes the assumptions of the theory of symbolic interactionism, according to which the mechanism shaping social structures and representations consists of constant exchange and evolution of meanings of symbols in the course of interactions among humans. Language encrypts reality through symbols included in the cultural code and the cultural code is shaped by language.

Language is the tool that gives meaning. The mechanism and functioning of language belongs to the main areas of interest and problems of cultural studies. Studies of culture are often perceived as studies of meaning created in a symbolic way by meaning systems that function like a language. From the perspective of cultural studies, just as from the perspective of sociology of knowledge, language is not treated as a neutral means of formulating and transmitting values, meanings and forms of knowledge that independently exist outside its structure, but rather as a causative factor. It is assumed that language gives meaning to material objects and social practices that become understood within the borders defined 
by the language (Barker, 2005, p. 101). The creative properties of language are related to the role language plays in shaping our perception and to the fact that social reality does not consist solely of "perceptual" objects that are directly experienced and may be objectively separated. It also consists of notional objects that owe their subjectivity to the fact that there is a word that makes it possible to distinguish them from the surrounding space as a separate thing.

Similar functions of language were underlined by one of the most famous psychologists, Gordon Allport, who discussed them in his classical work, The Nature of Prejudice (Allport, 1958). In his opinion, if words did not exist, we would be able to form only general categories. In order to maintain generalizations in our consciousness, be able to go back to them, think of them, and identify them, we must define them with words. Without words, as Allport writes referring to William James, our world would be like an "empirical sand-heap" (Allport, 1958, p. 174), which means that our experience of the world would resemble observing a huge volume of sand consisting of separate sand grains. Our empirical experience of the world consists of billions of grains corresponding to the category of "being a human". Our consciousness, however, cannot deal with large numbers of units. We have to group them into "bundles". And names help us to create such groups.

The most important property of nouns is the fact that they make it possible to group many "sand grains" into one set despite the same "grains" having features corresponding to another set. More precisely speaking, nouns describe one feature of the reality, grouping specific entities into one set by means of this one feature. This process or classification act entails omitting other features on the basis of which a completely different classification could be made.

Allport introduces the notion of labels, among them those with a particularly strong impact: "labels of primary potency" (Allport, 1958, p. 175). These are, for instance, labels referring to ethnicity (Black, Chinese) or disabilities, for instance a cripple or blind man.

In Allport's opinion, the majority of people are not aware how powerfully language affects the way they perceive reality, that every label applied to a given person draws our attention to one aspect of their nature. As he writes, one may say that a given man is for instance a philosopher, an athlete and Chinese, and a given person may have all these features. But none of them refers to the entire nature of the described person. Therefore, when it is used, every label, particularly of primary potency, detracts our attention from the true reality, resulting in the fact that the entire nature of the described object is not visible to our perception. Labels work like symbols and cause entities described by them also to be assigned a number of properties embedded in the symbol.

The role of labels initiating symbolic thinking can even be played by surnames. For instance the expression "Mr. Greenberg" provides us with ethnic associations, which initiates the entire symbol related to such ethnicity. Allport agrees with Margaret Mead that labels of primary potency lose some of their power when 
they are transformed from nouns into adjectives. In the expression "Jewish artist" or "Catholic teacher" the emphasis is split between two criteria and points our attention to the fact that reality is more complex.

As Allport writes, language builds a framework of mental categories and the corresponding emotions. This has an essential impact on the process of learning in childhood (Allport, 1958, p. 289). The impact of linguistic labels on a child's mental development is huge, also because children are more inclined to generalize.

Allport's theory is extremely inspiring. He draws our attention to the way in which criteria used to describe reality influence our thinking about reality, the way we perceive it and act. Referring to Allport's theory, Pratkanis and Aronson write: "it is the nature of language to divide up and categorize the buzzing boom of information that comes our way every second of the day. It is this inherent nature of language that gives it the power to persuade. By labeling someone a 'man', a 'woman', a 'philanthropist', an 'attractive Chinese', a 'physician', an 'athlete', we emphasize some particular feature of the object 'human being' over many other possible ones. We then respond to these features, organizing our realities around the label. Nouns that 'cut slices' - such as we-they, black-white, rich-poor, free-Soviet, male-female - serve to divide up the world into neat little packages and to imply the range of appropriate courses of action to take" (Pratkanis \& Aronson, 2003, p. 69).

\section{Historical-political semantics of asymmetric counterconcepts}

The importance of language when constructing social reality, and history, is also emphasized by Reinhard Koselleck (2001) in his book Futures Past. Koselleck begins his discussion on the relations between the history of notions and social history with a quotation from Epictetus: "It is not deeds that shock humanity, but the words describing them" (Koselleck, 2001, p. 130). And he continues: "It is a general property of language that each of the meanings of a word reaches further than the singularity to which historical events can lay claim. Each word, even each name, displays a linguistic potentiality beyond the individual phenomenon that it at a given moment characterizes or names. This is equally true of historical concepts, even if they initially serve to conceptually assemble the singularity of complex structures of experience. Once 'minted', a concept contains within itself, purely linguistically, the possibility of being employed in a generalized manner, of constructing types, or of disclosing comparative insights. The reference to a particular party, state, or army linguistically involves a plane potentially including parties, states, or armies. A history of related concepts leads to structural questions that social history has to answer" (Koselleck, 2001, pp. 151-152).

Koselleck's work is extremely inspiring from a theoretical perspective. From the point of view of our analysis, the most important issue is discussed in detail 
in the chapter devoted to the problem of historical-political semantics of asymmetric counterconcepts.

Like Allport, Koselleck assumes at the start of his analysis that words define reality. As he writes, defining oneself and others is an everyday practice of humans (Koselleck, 2001). Such definitions articulate the identity of a given person and his or her attitude toward others. It makes a difference whether "others" are defined by means of stigmatizing or disparaging words, or by means of names that imply linguistic recognition. People may use the same expressions or each person may use different expressions to define "others" than they use to define themselves. For a situation in which someone uses name words implying linguistic recognition to describe themselves and disparaging name words to define "others", Koselleck introduces the term of asymmetric counterconcepts.

The impact of such mutual allocations is enhanced from a historical perspective if they concern groups. Ordinary use of the words "we" and "you" typically includes someone in a community or excludes them from it, Koselleck writes. However, a group is able to become a politically efficient agency that describes itself with the predicate "we" as a result of notions that include something more than simple specification or naming. "A political or social agency is first constituted through concepts by means of which it circumscribes itself and hence excludes others, and therefore by means of which it defines itself. A group may empirically develop on the basis of command or consent, of contract or propaganda, of necessity, of kinship, and so forth; but however constituted, concepts are needed within which the group can recognize and define itself, if it wishes to present itself as a functioning agency. In the sense used here, a concept does not merely denote such an agency, it marks and creates the unity. The concept is not merely a sign for, but also a factor in, political or social groupings" (Koselleck, 2001, p. 229).

Koselleck analyses the structure and mechanism of creating counterconcepts reflecting the axiological hierarchy of cultures. As he writes, there are innumerable concepts of this kind which, while being concretely applied, have a general utility. For instance, an acting agency may define itself as a nation, party, stand, society, or state without preventing those excluded from determining themselves by means of the same terms. However, from a historical perspective numerous agencies tend to transfer general concepts into their individual sphere, to use such concepts in order to define and understand themselves only. For a Catholic, "the Church" may mean only his own church, "the nation" may be perceived only as one's own nation. In such cases one may say that a group makes an exclusive claim to generality, applying a linguistically universal concept to itself alone. This kind of self-definition provokes counterconcepts which discriminate against those excluded. And so "the non-Catholic becomes heathen or traitor; to leave the Communist party does not mean to change party allegiance, but is rather 'like leaving life, leaving mankind'; not to mention the negative terms that 
European nations have used for each other in times of conflict and that were transferred from one nation to another according to changing balance of power" (Koselleck, 2001, p. 230).

Koselleck discusses the problem on the example of a historical analysis of the semantic opposition of "Hellene" and "Barbarian", "Christian" and "Heathen", "human" and "non-human". As he writes, there have been numerous counterconcepts in history aiming to preclude mutual respect. Self-expression gives rise to an opposing expression that stigmatizes the alien and results in counterconcepts. Their opposition is based on the fact that they do not contrast evenly with each other. "The linguistic usage of politics, like that of everyday life, is permanently based on this fundamental figure of asymmetric opposition" (Koselleck, 2001, p. 230). And so, individuals who do not belong to the group of "Hellenes" are automatically included in the group of "Barbarians"; everyone who is not included in the group of "Christians" shall be automatically called "Heathen" and everybody who is not considered to be a "true human" is deprived of humanity, which automatically leads to the dehumanization of entire ethnic, religious, cultural or racial groups.

Koselleck points to the extremely important problem of the consequences of using certain rhetorical devices, in this case asymmetric counterconcepts, for the practical aspects of social and political life. Appropriation of universal concepts for one's own group alone is dangerous, it leads to polarization of societies, disparaging of "opponents", it prevents reconciliation and the discussions on which the functioning of democratic societies is based. Use of asymmetric counterconcepts is a great manipulation of society by means of language. All expressions such as "we, true" Germans, French or Poles, or we the only true worshippers of God, are never innocent, they always lead to exclusion from the community and total discrediting of all who are outside the group.

\section{On dogmatic narrations}

Politicians used the mechanism described by Koselleck many times in different historical periods, and unfortunately they were very successful. The social engineering method of creating two hostile groups by means of language, dividing the world into the group of US, which is related to none but positive features, and the group of THEM that is related to all features from the realm of evil, was successfully used by Soviet and Nazi totalitarianism, as well as the language of communism in Poland and other countries of the Soviet bloc. Victor Klemperer (Klemperer, 1989), Francoise Thom (Thom, 1990), Michał Głowiński (Głowiński, 1990) and Jerzy Bralczyk (Bralczyk, 2003) all emphasize the importance of social engineering for totalitarian narration. The structure of totalitarian narration has been and still is (North Korea) built on the Manichaean vision of the world, on the opposition of We-They (Jakubowska-Branicka, 2013). 
Narrations of this kind, which I call dogmatic narrations (JakubowskaBranicka, 2013), are not a thing of the past like the totalitarianisms of the 20th century. Also today, in democratic times, they are often used and are a useful tool for numerous political and social groups. They are useful because dogmatic narrations arouse strong emotions that can be used as weapons in political fighting and often involve large segments of society in such fighting.

Klemperer, Thom, and Głowiński all emphasize the significant impact of the picture of reality created by totalitarian language on the mental structures of individuals through which they perceive and define reality. An analysis of totalitarian language reveals pictures of reality that have common features. The most significant of them is Manichaeism, expressed by a restrictive division into "good" and "evil" that is strictly related to the WE and THEY categories. The figure of the enemy necessarily coexists with the Manichaean vision of the world, with all the consequences for how that enemy is treated. Hanna Świda-Ziemba (Świda-Ziemba, 1997), sociologist, analyzes deformations of the perception of reality as a consequence of a totalitarian vision of the world. The dichotomous principle of structuring reality, presenting the world as a struggle between the dark and light sides, determines the structure of thinking typical for totalitarianism, resulting in individuals perceiving the world in a black-and-white paradigm. People are evaluated not according to who they are but according to the groups to which they belong, which implies a division into "us" and "others", where such "others" are automatically put in the position of an enemy. Jerzy Trzebiński (Trzebiński, 2002), psychologist, similarly emphasized the role and meaning of narration for the way in which reality is perceived and defined by an individual. He defines narration as the way in which the world is understood by people, the way in which knowledge on reality is provided. Such knowledge creates cognitive schemes. A cognitive scheme is a model of an element of reality that performs two basic functions related to each other: representation of reality and processing of information on such reality. Narrative schemes impose the manner of interpretation of reality - the mind interprets occurring events as stories and the narrative interpretation of occurring events is limited by these schemes, or rules of interpreting reality. In this sense, a narrative scheme is a cognitive procedure of "reading" a course of events. A narrative scheme in a general way defines the fundamental features of possible stories by means of which an individual is able to interpret a given sphere of his or her own life in a way that he or she can understand. An activated scheme, in this sense, results in narrative construction of reality by the individual. In summary, known narrations about reality create an individual's structures and cognitive schemes, and these determine perception and defining of new events in compliance with such schemes. This is a situation offering the possibility to completely control and steer the way in which reality is perceived by an individual, and thus his or her thinking. 
If we adopt such a point of view, totalitarian narrations about reality will shape individuals who perceive reality in the black-and-white paradigm with all the consequences of that fact. Unfortunately the results of already conducted research confirm this hypothesis.

\section{The results of international comparative studies: dogmatism and worldview liberalism}

An international comparative research project involving the United States, France, Spain, Hungary, Poland, Bulgaria and Russia was conducted in 1996 (Jakubowska-Branicka, 2013). The research was carried out as part of an international project financed by the National Science Foundation (SES 9213237 \& SBR 93 11403). The study, performed on a representative sample in every country mentioned above, was conducted by specialist research centers. In Poland this was $\mathrm{CBOS}^{2}$. I was one of the researchers in the project. In 2007 and 2009 I repeated the part of the study that was of special interest to me, on a representative countrywide sample; the research was again conducted by CBOS. At this point I would like to quote the most essential results from the point of view of this analysis, i.e. those related to dogmatism and worldview liberalism.

In the aforementioned research, dogmatism was understood in compliance with the theoretical proposition of Milton Rokeach. Since the notion of dogmatism assumes determining the features of a person's way of thinking and that person's structure of beliefs in formal terms, i.e. free from any ideological content, the research disregarded the structure of beliefs related to the respondents' systems of values. The researchers focused on examining the essence of dogmatism, namely the relation between the system of accepted opinions and those that are not accepted by a person. Disapproved opinions may be rejected with various intensity. The more dogmatic the mind, the stronger the intensity of rejection of opinions different from one's own. And, the smaller the dogmatism, the stronger the tolerance toward opinions with which a person disagrees. Moreover, greater dogmatism of mind is associated with greater psychological isolation of the two systems of beliefs, with an inclination to emphasize differences and minimize similarities between accepted and unaccepted things. The lesser the dogmatism, the more willing the individual is to notice elements common to both systems of beliefs. Consequently, a high level of dogmatism is related to a strong inclination to separate "the one and only truth" from the remaining opinions that are mindlessly considered to be "false". Truth that is considered to be "the only proper truth" represents an absolute and arbitrary authority that is not subject to evaluation. As a consequence of unlimited confidence in authority, of acquiring extreme beliefs, conformity or

\footnotetext{
${ }^{2}$ Public Opinion Research Centre.
} 
non-conformity to "truths" presented by the authority is adopted as a criterion for evaluating others. Intolerance and non-acceptance of someone else's beliefs makes people treat compromises, coalitions and cooperation with "others" as a betrayal of their own beliefs. A high level of dogmatism is usually related to a high level of danger from the external world, therefore a dogmatic individual looks for security in identification with authorities and a group to which he or she belongs. Every factor perceived as a threat to the position of the authority or the group's cohesion is considered to be negative.

In order to account for the above-mentioned features of dogmatism, the researchers constructed four questions, treating them as indicative of a dogmatic mentality. No question referred directly to the respondent's attitude toward abstract or real authority, but invoking the theory of dogmatism we assumed that "the longing for truth" that is typical of a dogmatic individual always creates an authority that embodies such truth.

Two fundamental features of dogmatism were emphasized: a dichotomous perception of reality in terms of Truth (with a capital "T") and falsehood, and readiness for social compromise with persons representing different worldviews. The indicating questions for dogmatism were as follows: (1) There are two types of people in the world: people who support truth and those against the truth; (2) A group that allows too many differences in its members' opinions cannot survive long. (3) A compromise made with political enemies is dangerous, since it always entails betrayal of one's own position. (4) Among all the different philosophies in the world probably only one is true. The respondents were asked to mark their attitudes toward each question on a scale ranging from "I strongly agree" to "I strongly disagree".

The results of this international comparative study show that most often the following respondents are ranked highly on the scale of dogmatism: in Bulgaria - 77.9\%, Russia - $73.1 \%$ and Poland $-69.5 \%$, followed by France $-59.4 \%$ and Hungary $-54.2 \%$, and least frequently in Spain - 35.2\% and the United States $33.5 \%$. Statistical analyses show that a high location on the scale of dogmatism depends mainly on two factors: a low level of education and having spent one's life in an undemocratic country. During the 13 years between the first and last study, the frequency of dogmatic declarations fell in Poland; 66.7\% of respondents in 2007 and $58.0 \%$ in 2009 declared high dogmatism. Thus, it seems that progress in Poland's democratization is having a positive impact on the mentality of Poles. However, almost $60 \%$ of respondents in Poland are still not willing to reach any kind of compromise with people who have different opinions and, even worse, people who are prepared to reach an agreement are considered to be traitors. Therefore, this result cannot be considered optimistic from the point of view of the needs of a democratic country.

The contradictory variable in relation to dogmatism was termed "worldview liberalism". The most essential feature of worldview liberalism is a permissive 
and tolerant attitude toward the opinions, attitudes and acts of other people, regardless of whether they are considered right or not, a conciliatory manner and the ability to reach a compromise in relations with other people. The indicating questions for worldview liberalism are as follows:

(1) It is better to live in a disciplined society than let people have so much freedom that it will be threatening for the order; (2) Freedom of speech is too costly if it means that we have to put up with threats resulting from extreme political opinions; (3) Society should not tolerate political opinions that are fundamentally different from the opinions of the majority; (4) Since demonstrations often result in disorganization and are threatening to the order, radical and extreme political groups should not be allowed to demonstrate.

Similarly to the questions about dogmatism, respondents could express their opinion about each statement on a scale from "I strongly agree" to "I strongly disagree".

The results of the international comparative study show that respondents in the United States $-67.2 \%$, Spain $-58.2 \%$ and France $-49.7 \%$ are high on the scale of worldview liberalism understood in the above way. In the post-communist countries worldview liberalism is declared much less frequently: in Hungary $26.6 \%$, in Russia -25.3 , in Poland $-23.0 \%$, and in Bulgaria $-17.2 \%$ of respondents. Thus, it is clear that in the "old" democracies respondents are much more tolerant toward differences and are more eager to see worldview pluralism in society. A high place on the worldview liberalism scale is also related to higher education.

In the 13 years from the first study the frequency of declarations of tolerance toward differences grew in Poland. In $2007-30.9 \%$ and in $2009-30.4 \%$ of respondents gave answers pointing to their tolerance toward different worldviews. We may say that like in the case of dogmatism, the progressing democratization of Poland has contributed to changes in mentality within the discussed scope. We are becoming more tolerant and less dogmatic, and less unwilling to act in agreement and cooperation with people who have different opinions.

In summary, it needs saying that the results presented above are alarming. Obviously, it is difficult to define precisely what variables have affected this kind of social mentality in Poland and other post-communist countries. In the context of the above analysis, however, it seems reasonable to assume that it was the language and shape of narration typical for totalitarianism that contributed to such a situation.

Due to the overwhelming dichotomization of created reality, any agreement with the "enemy", any declaration of concurring with the "enemy's" opinions, is considered a betrayal of one's own group and one's own worldview attitudes. Any contacts maintained with the "enemy" result in exclusion from the WE group, sanctions and the label of enemy. Such a mechanism is extremely dysfunctional 
for the efficient functioning of democratic systems and harmony of interpersonal relationships, leading to social disintegration and atomization.

What, then, is the relationship between reality and language? Does language describe or create reality? Answering these questions is very important from a theoretical point of view, but it is no less essential for social practice.

\section{References}

Allport, G.W. (1958). The Nature of Prejudice. New York: Addison-Wesley Publishing Company.

Barker, C. (2005). Studia kulturowe. Teoria i praktyka [Cultural Studies: Theory and Practice] (translated by A. Sadza). Kraków: WUJ.

Berger, P. \& Luckmann, T. (1983). Społeczne tworzenie rzeczywistości [The Social Construction Of Reality] (translated by Józef Niżnik). Warszawa: PIW.

Blumer, H. (2007). Interakcjonizm symboliczny. Perspektywa i metoda [Symbolic Interactionism. Perspective and Method] (translated by G. Woroniecka). Kraków: Nomos.

Bokszański, Z. (2006). Tożsamości zbiorowe [Collective Identities]. Warsaw: Wydawnictwo Naukowe PWN.

Bralczyk, J.(2003). Ojezzyku polskiej propagandy politycznej lat siedemdziesiatych [On the Language of the Polish Political Propaganda of the 1970s]. Warszawa: TRIO.

Głowiński, M. (1990). Nowomowa po polsku [Newspeak in Polish]. Warszawa: PEN. Jakubowska-Branicka, I. (2013). O dogmatycznych narracjach. Studium nienawiści [About Dogmatic Narrations. Hate Studies], Warszawa: TRIO.

Klemperer, V. (1989). LTI. Notatnik filologa [LTI. Notizbuch eines Philologen] (translated by J. Zychowicz). Warszawa: Młodzieżowa Agencja Wydawnicza.

Koselleck, R. (2001). Semantyka historyczna [Futures Past] (translated by W. Kunicki). Poznań: Wydawnictwo Poznańskie.

Marshall, G. (Ed.) (2005). Oxford. Stownik socjologii i nauk spotecznych [Oxford Dictionary of Sociology and Social Sciences] (Polish edition by M. Tabin). Warszawa: Wydawnictwo Naukowe PWN.

Niżnik, J. (1983). Stowo wstęne [Foreword]. In P.L. Berger \& T. Luckmann, Społeczne tworzenie rzeczywistości. Traktat z socjologii wiedzy [The Social Construction of Reality: A Treatise in the Sociology of Knowledge] (translated by J. Niżnik; pp. 5-17). Warszawa: PIW.

Olechnicki, K. \& Załęcki, P. (1999). Stownik socjologiczny [Dictionary of Sociol$o g y]$. Toruń: Graffiti.

Pratkanis, A. \& Aronson, E. (2003). Wiek propagandy [The Age of Propaganda] (translated by J. Radzicki \& M. Szuster). Warszawa: Wydawnictwo Naukowe PWN.

Schütz, A. (2008). O wielości światów [On Multiple Realities] (translated by B. Jabłońska). Kraków: Nomos. 
Skarżyńska, K. (2011). Człowiek a polityka. Zarys psychologii politycznej [Man vs. Policy. Outline of Political Psychology]. Warszawa: Wydawnictwo Naukowe Scholar.

Świda-Ziemba, H. (1997). Człowiek wewnętrznie zniewolony. Problemy psychosocjologiczne minionej formacji [Inherently Enslaved Man. Psychosociological Problems of the Past Formation]. Warszawa: ISNS UW.

Thom, F. (1990). Drewniany jezzyk [La langue de bois] (translated by I. Bielicka). Warszawa: CDN.

Trzebiński, J. (2002). Narracja jako sposób rozumienia świata [Narration as the Way to Understand the World]. Gdańsk: GWP. 